Published in "Natural Product Research doi: 10.1080/14786419.2019.1636243, 2019"

which should be cited to refer to this work.

\title{
Contortamide, a new anti-colon cancer cerebroside and other constituents from Tabernaemontana contorta Stapf (Apocynaceae)
}

Guy R. Ebede ${ }^{\mathrm{a}, \mathrm{d}}$, Joseph T. Ndongo ${ }^{\mathrm{b}}$, Joséphine N. Mbing ${ }^{\mathrm{a}}$, Hector C. M. Kenfack ${ }^{c}$, Dieudonné E. Pegnyemb ${ }^{a}$ and Christian G. Bochet ${ }^{d}$

\begin{abstract}
aDepartment of Organic Chemistry, Faculty of Science, University of Yaoundé I, Yaoundé, Cameroon; bDepartment of Chemistry, Higher Teacher Training College, University of Yaoundé I, Yaoundé, Cameroon; 'Department of Biochemistry, Faculty of Science, University of Dschang, Dschang, Cameroon; 'Department of Chemistry, Faculty of Science and Medicine, University of Fribourg, Fribourg, Switzerland
\end{abstract}

\begin{abstract}
A new cerebroside, Contortamide (1) together with nine known compounds spegatrine (2), affinisine (3), Nb-methylaffinisine (4), ursolic acid (5), $\alpha$-amyrin (6), bauerenol acetate (7), lupeol (8), betulinic acid (9) and $\beta$-sitosterolglycoside (10) were isolated from the trunk bark of Tabernaemontana contorta Stapf. The new compound 1 showed significant activity against Caco-2 colon cancer cells with the MTT method. Compounds 1-4 and 6-9 were isolated for the first time from this species.
\end{abstract}
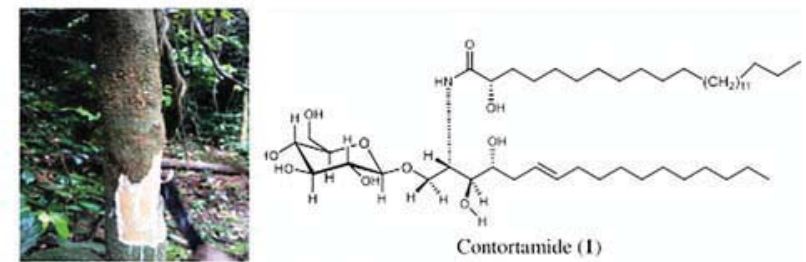

Trunk of Tabernaemontana contorta Stapf

\section{KEYWORDS}

Contortamide;

Tabernaemontana contorta

Stapf; Apocynaceae;

colon cancer

\section{Introduction}

The genus Tabernaemontana that consists of about 110 species is pantropical. About 18 species exist in the African continent and 15 in Madagascar. The species Tabernaemontana contorta Stapf is similar to the pachysiphon species. It is found in Madagascar (Bui et al. 1977), Nigeria and Cameroon (Patel et al. 1967). Plants of the genus Tabernaemontana are used in several fields. Tabernaemontana catharinensis is used to reduce toothache, remove tumors from the epidermis and as an antidote

CONTACT J. T. Ndongo thierry.ndongo@ens.cm

(6) Supplemental data for this article can be accessed 
for snakebite (Leeuwenberg 1994; Pereira et al. 2008). Tabernaemontana contorta Stapf., a flowering plant, belongs to the family Apocynaceae. In Cameroon, its leaves are used to prevent keloids formation and as antiseptic (Burkill 1985). Indole alkaloids are useful chemical markers of the genus Tabernaemontana. Coronaridine, an ibogatype indole alkaloid, has been isolated from over 50 Tabernaemontana species and can thus be inferred as a chemotaxonomic marker of the genus (Garcellano et al. 2019). However, this genus contains a considerable presence of phenolic compounds identified in the ethyl acetate fraction of Tabernaemontana catharinensis (Pauleti et al. 2018). Two bisindoline alkaloids, contortarine A, 16-epi-pleiomutinine, pleiomutinine, and five others alkaloids, 1-carbomethoxy- $\beta$-carboline, strictosidine lactam, pleiocarpamine and pleiocarpine were isolated from the roots of Tabernaemontana contorta Stapf (Ndongo et al. 2017). From the fruits of this plant, two new indole alkaloid derivatives, 5,6-dioxo-11-methoxy voacangine and (-)-apparicin-21-one, together with four known compounds, voacangine, ursolic acid, 3-methoxyursolic acid and asiatic acid were isolated (Foudjo Melacheu et al. 2019). In our ongoing search for bioactive secondary metabolites from Cameroonian Tabernaemontana species, isolation of the constituents of the trunk bark of Tabernaemontana contorta was carried out. As results, a new cerebroside (1) together with nine know compounds (2-10) were isolated. In this article, we wish to describe the isolation and structural elucidation of this new compound as well as the evaluation of the anti-colon cancer activity of some of them.

\section{Results and discussion}

The methanol extract of trunk bark of Tabernaemontana contorta Stapf was fractionated by column chromatography on silica gel using a dichloromethane/methanol solvent system with increasing polarity to give eight fractions. The two first fractions were chromatographed on silica gel columns to give ten compounds 1-10 (Figure 1). Compound 1 was isolated as a white amorphous solid, $[\alpha]_{D}^{25}-27.5$ (c $0.020, \mathrm{CHCl}_{3}$ ) $\mathrm{MeOH})$. The HRESI-MS showed a quasi-molecular ion peak $[\mathrm{M}+\mathrm{Na}]{ }^{+}$at $\mathrm{m} / \mathrm{z}$ 866.67244 suggesting a molecular formula of $\mathrm{C}_{48} \mathrm{H}_{93} \mathrm{O}_{10} \mathrm{~N}$ and fragment ion at $\mathrm{m} / \mathrm{z}$ 381. Its IR spectrum showed absorption bands at 3393 and $3313 \mathrm{~cm}^{-1}$ (br, NH and $\mathrm{OH}), 1737$ and $1631 \mathrm{~cm}^{-1}$ (amide group CO), 2920-2851 $\mathrm{cm}^{-1}$ (aliphatic chain), $1467 \mathrm{~cm}^{-1}$ (double bond) and 1079 and $1034 \mathrm{~cm}^{-1}$ for C-O-C absorptions. The ${ }^{1} \mathrm{H}$ NMR spectra (Table S1) of 1 indicated a broad signal range of $\delta_{\mathrm{H}} 1.28-1.40$ (brs, $\mathrm{CH}_{2}$ group) and a triplet at $\delta_{\mathrm{H}} 0.89(6 \mathrm{H}, J=6.7 \mathrm{~Hz}$, two terminal methyl groups) assigned to two long aliphatic chains. The proton signal at $\delta_{\mathrm{H}} 4.29(\mathrm{~d}, J=7.8 \mathrm{~Hz})$, displayed the presence of an anomeric proton of a sugar residue and its coupling constant supports the $\beta$-configuration of the glucose. However, a pair of olefinic protons at $\delta_{\mathrm{H}} 5.41(1 \mathrm{H}$, $\mathrm{dt}, \mathrm{H}-6)$ and $5.36(1 \mathrm{H}, \mathrm{dt}, \mathrm{H}-7)$ revealed the presence of one olefinic bond. In the ${ }^{13} \mathrm{C}$ NMR spectrum, the signals at $\delta_{\mathrm{C}} 103.3,73.6,76.5,70.2,76.7$ and 61.3 confirmed the glucopyranose moiety in 1 . A signal of a methine carbon bearing nitrogen at $\delta_{\mathrm{C}} 50.3$ $(\mathrm{C}-2)$, an oxymethylene carbon resonated at $\delta_{\mathrm{C}} 68.5(\mathrm{C}-1)$, along with three resonances of oxymethine carbons at $\delta_{\mathrm{C}} 74.4$ (C-3), 71.4 (C-4), $71.5\left(\mathrm{C}-2^{\prime}\right)$ and an amide carbonyl signal at $\delta_{\mathrm{C}} 176.2\left(\mathrm{C}-1^{\prime}\right)$. The $\Delta[6,7]$ olefinic bond was confirmed to have a (E)-configuration as evidenced by the coupling constants $(J=14.4 \mathrm{~Hz})$, together with the 


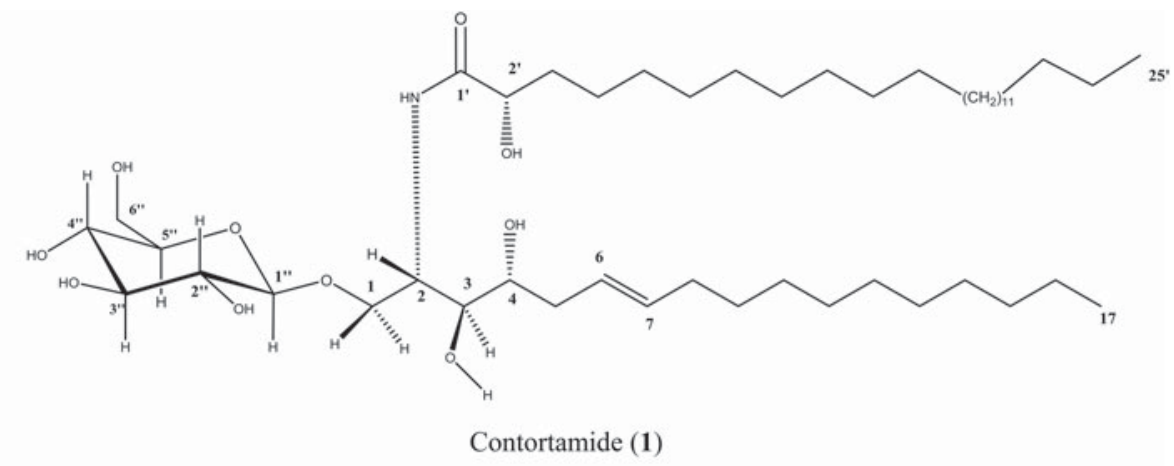

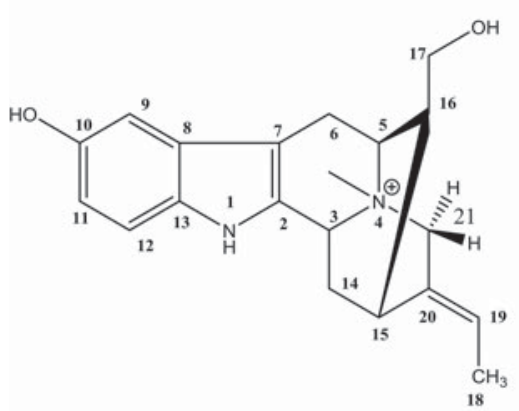

Spegatrine (2)

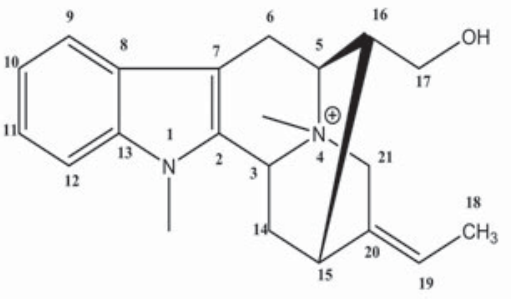

$\mathrm{N}_{\mathrm{b}}$-Methyl affinisine (4)

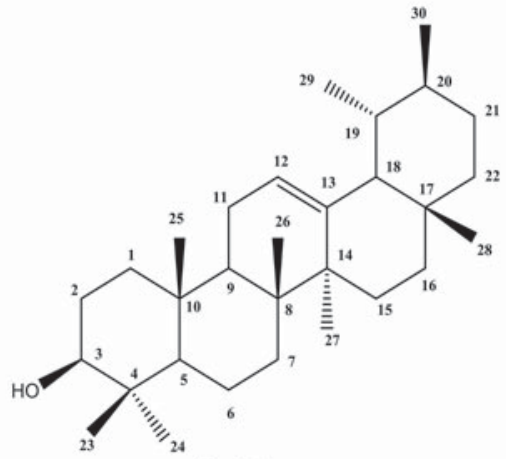

$\alpha$-amyrin (6)

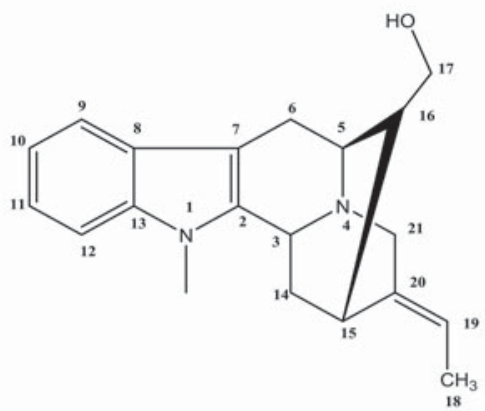

Affinisine (3)

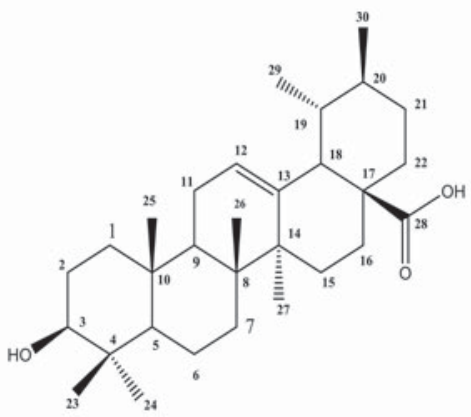

Ursolic acid (5)

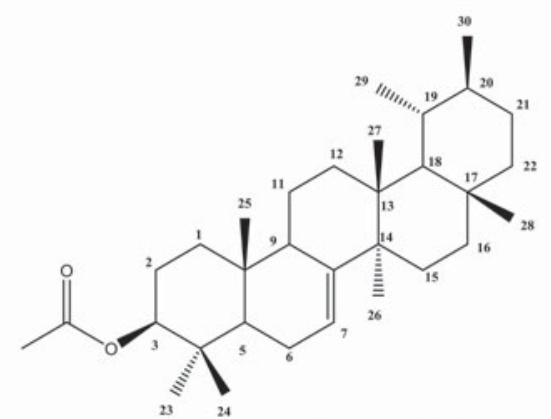

Bauerenol acetate (7)

Figure 1. Chemical structures of the isolated compounds (1-10). 


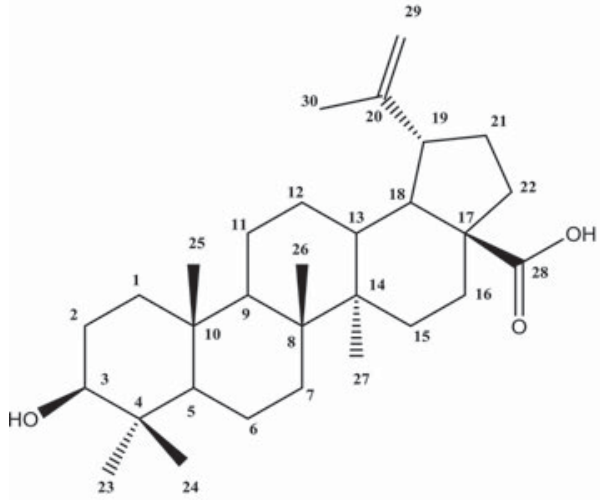

Lupeol (8)

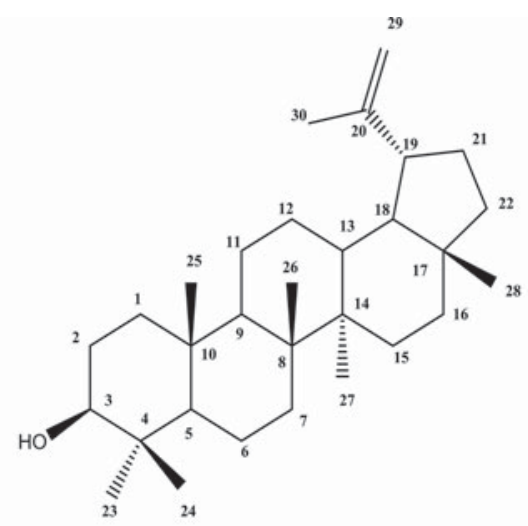

betulinic acid (9)

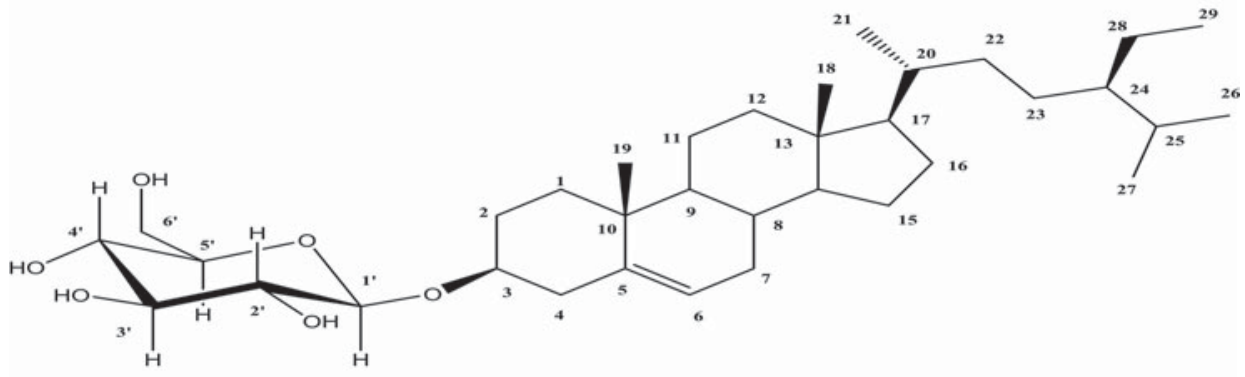

$\beta$-sitosterol-D-glycoside (10)

Figure 1. Continued

chemical shifts of $\mathrm{C}-5$ at $\left(\delta_{\mathrm{C}} 32.4\right)$ and $\mathrm{C}-8\left(\delta_{\mathrm{C}} 32.0\right)$. Typically, the signals of a carbon next to a trans double bond appear between $\delta_{\mathrm{C}} 32$ and 33 (Ai-Qun et al. 2010; Huang et al. 2010), while those of a cis double bond appear between $\delta_{\mathrm{C}} 27$ and 28 (Liu et al. 1999). This configuration was also confirmed by the band at $965 \mathrm{~cm}^{-1}$ in the $I R$ spectrum, vibration of deformation of the bond $=\mathrm{C}-\mathrm{H}$, characteristic of a system $\mathrm{R}$ $\mathrm{CH}=\mathrm{CH}-\mathrm{R}^{\prime}$ trans. The position of the double bond could be deduced from the following evidence: The proton at $\delta_{\mathrm{H}} 2.01(\mathrm{H}-5)$ showed ${ }^{2} \mathrm{~J}-\mathrm{HMBC}$ correlation with carbon at $\delta_{\mathrm{C}} 129.4(\mathrm{C}-6)$, whereas $\mathrm{HMBC}$ and COSY cross signals were observed between C- 6 and the olefinic proton at $\delta_{\mathrm{H}} 5.41(\mathrm{H}-5), \mathrm{H}-5$ and $\mathrm{H}-6, \mathrm{H}-5$ and $\mathrm{H}-4$ and between $\mathrm{H}-4$ and $\mathrm{H}-3$, respectively. These results suggested that 1 might belong to the sphingolipid class of compounds (Huang et al. 1995). The spatial location of hydroxyl groups in sphingosine was evident by exploitation of NOESY spectrum (Figure S9) which showed interactions between the protons at $\delta_{\mathrm{H}} 3.57$ and 3.79 supporting that the two protons were in the same spatial orientation. The absolute configurations of C-2 and C-3 in all sphingolipids isolated from natural plants were $2 S, 3 R$, respectively (Karlsson 1970). The relative configuration of C-4 was both determined to be $R$ and $S$ for $C-2$ ' by comparing the chemical shift with previously reported data (Gao et al. 2001; Zhan and Yue 2003). Based on these evidences, (1) could be assigned the structure 1-O- $\beta$-Dglucopyranosyl-(2S,3R,4R,6E)-2-[(2'S)-2'-hydroxypentacosanoylamino]-1,3,4-heptandecanetriol-6-ene (Figure 1) and named contortamide (1). The known compounds were 
identified as spegatrine (2) (Ndongo et al. 2018), affinisine (3) and $\mathrm{N}_{\mathrm{b}}$-methylaffinisine (4) (Monnerat et al. 2005), ursolic acid (5) (Foudjo Melacheu et al. 2019), $\alpha$-amyrin (6) and bauerenol acetate (7) (Carothers et al. 2018), lupeol (8) and betulinic acid (9) (Pereira et al. 2008), $\beta$-sitosterolglycoside (10) (Rahmana et al. 2009) by comparison of physical and reported NMR data in the literature.

Methanolysis $\left(0.9 \mathrm{~N}, \mathrm{HCl} / \mathrm{MeOH}\right.$, at $70^{\circ} \mathrm{C}$ during $\left.18 \mathrm{~h}\right)$ of compound 1 gave the fatty acid methyl ester (Figure S13) and the long chain base which were characterized by ESI-MS analysis. The peak at $\mathrm{m} / \mathrm{z} 413$ corresponded to a fatty acid methyl ester. The results of the cytotoxicity assay toward human colonic cancer cell line Caco-2 are shown on Figure S16. Both fraction and extract did not show any cytotoxic activity Caco-2 cell line at the tested concentration. Meanwhile, among the pure compounds, the new isolated Contortamide presented a good cytotoxic activity $(62.13 \pm 3.28 \%$ inhibition). Only this new compound (1) affects the growth of human colonic cancer cell line Caco-2 (Figure S15).

\section{Experimental}

\subsection{General experimental procedures}

FT-IR spectra were obtained on a FT-IR Tensor 27 spectrometer (Bruker). NMR spectra were recorded on a Bruker AM400 FTNMR spectrometer using TMS as an internal standard. ESI-MS and HRESI-MS were performed on a MicrOTOF-Q mass spectrometer (Bruker). All measurements were made at the Department of Chemistry (Faculty of science and medicine, University of Fribourg, Switzerland). TLC was performed on silica gel $60 \mathrm{~F}_{254}$ (1.05554.0001, Merck, Darmstadt, Germany) and RP-18 $F_{2545}$ plates (1.15685.0001, Merck, Darmstadt, Germany). Column chromatography was performed on silica gel (240-430 mesh, Merck, Darmstadt, Germany).

\subsection{Plant material}

Tabernaemontana contorta Stapf. (Apocynaceae) was collected from Mont Kalla (Nkolbison, at $8 \mathrm{~km}$. W. of Yaoundé) at the Centre Region of Cameroon in January 2017 and taxonomically identified by Mr. Victor Nana (Botanist at National Herbarium, Yaoundé, Cameroon). A voucher specimen ( $\mathrm{N}^{\circ} 43440 / \mathrm{HNC}$ ) was deposited National Herbarium in Yaoundé, Cameroon.

\subsection{Extraction and isolation}

Dried trunk bark of Tabernaemontana contorta Stapf $(1.4 \mathrm{~kg})$ was powdered and extracted at room temperature with $\mathrm{MeOH}(3 \times 4 \mathrm{~L})$ for 1 week. The crude extract was concentrated to dryness in a rotary evaporator at $40^{\circ} \mathrm{C}$ to obtain a gummy residue $(72.8 \mathrm{~g})$. The residue was chromatographed on silica gel column to give eight fractions using a $\mathrm{CH}_{2} \mathrm{Cl}_{2} / \mathrm{MeOH}$ solvent system with increasing polarity: $\mathrm{A}\left(\mathrm{CH}_{2} \mathrm{Cl}_{2}: \mathrm{MeOH}, 50: 1\right.$; $9.81 \mathrm{~g}), \mathrm{B}\left(\mathrm{CH}_{2} \mathrm{Cl}_{2}: \mathrm{MeOH}, 40: 1 ; 9.17 \mathrm{~g}\right), \mathrm{C}\left(\mathrm{CH}_{2} \mathrm{Cl}_{2} / \mathrm{MeOH}, 35: 1 ; 6.18 \mathrm{~g}\right), \mathrm{D}\left(\mathrm{CH}_{2} \mathrm{Cl}_{2}: \mathrm{MeOH}\right.$, $30: 1 ; 3.37 \mathrm{~g}), \mathrm{E}\left(\mathrm{CH}_{2} \mathrm{Cl}_{2}: \mathrm{MeOH}, 25: 1 ; 5.66 \mathrm{~g}\right), \mathrm{F}\left(\mathrm{CH}_{2} \mathrm{Cl}_{2}: \mathrm{MeOH}, 20: 1 ; 6.34 \mathrm{~g}\right), \mathrm{G}$ $\left(\mathrm{CH}_{2} \mathrm{Cl}_{2}: \mathrm{MeOH}, 10: 1 ; 2.64 \mathrm{~g}\right), \mathrm{H}\left(\mathrm{CH}_{2} \mathrm{Cl}_{2}: \mathrm{MeOH}, 1: 1 ; 6.37 \mathrm{~g}\right)$. Fraction (B) was further 
separated on silica gel $(40-60 \mu \mathrm{m})$ column eluted with $\mathrm{CH}_{2} \mathrm{Cl}_{2}: \mathrm{MeOH}$ (1\% to $\left.100 \%\right)$ to afford 7 sub-fractions (B1-B7). Later, sub-fraction B2 was chromatographed over silica gel $(32-40 \mu \mathrm{m})$ column by using hexane:ethyl acetate as mobile phase with gradient elution (1\% to $50 \%)$ to afford nine compounds: $\mathbf{2}(3.4 \mathrm{mg}), \mathbf{3}(5.2 \mathrm{mg}), \mathbf{4}(3.3 \mathrm{mg}), \mathbf{5}$ (7 mg), 6 (6 mg), 7 (4.5 mg), 8 ( $2.3 \mathrm{mg}), 9(2 \mathrm{mg})$, and 10 (10 mg). Fraction E was further chromatographed on a silica gel column $(32-40 \mu \mathrm{m})$ using $\mathrm{CH}_{2} \mathrm{Cl}_{2}: \mathrm{MeOH}$ (1\% to $100 \%$ ) as solvent system to yield new compound $\mathbf{1}(5.7 \mathrm{mg})$.

\subsubsection{Contortamide (1)}

White amorphous powder; $[\alpha]_{D}^{25}-27.5$ (c $\left.0.020, \mathrm{CHCl}_{3} / \mathrm{MeOH}\right) ; \mathrm{TLC}$ Rf: $0.70\left(\mathrm{CH}_{2} \mathrm{Cl}_{2}\right.$ / $\mathrm{MeOH}, 15 / 1) ; \mathrm{IR}(\mathrm{AgCl}) \mathrm{cm}^{-1}: 3393,2953,2851,1727,1631,1321,1299,1079,1034$; HRESI-MS $[\mathrm{M}+\mathrm{Na}]^{+} \mathrm{m} / \mathrm{z} 866.67244$ (calcd for $\mathrm{C}_{48} \mathrm{H}_{93} \mathrm{O}_{10} \mathrm{~N}: 843.6799$ ).

${ }^{1} \mathrm{H}-\mathrm{NMR}\left(\mathrm{CD}_{3} \mathrm{OD}, 400 \mathrm{MHz}\right)$ and ${ }^{13} \mathrm{C}-\mathrm{NMR}\left(\mathrm{CD}_{3} \mathrm{OD}, 100 \mathrm{MHz}\right)$ data, see Table S1.

${ }^{1} \mathrm{H}-\mathrm{NMR} \quad\left(\mathrm{CD}_{3} \mathrm{OD}, 400 \mathrm{MHz}\right): \delta_{\mathrm{H}}: 5.40(1 \mathrm{H}, \mathrm{dt}, \mathrm{H}-6, J=14.4 \mathrm{~Hz}), 5.46(1 \mathrm{H}, \mathrm{dt}$, $J=14.4 \mathrm{~Hz}, \mathrm{H}-7), 4.26\left(1 \mathrm{H}, \mathrm{d}, J=7.8 \mathrm{~Hz}, \mathrm{H}-1^{\prime \prime}\right), 4.24(1 \mathrm{H}, \mathrm{m}, \mathrm{H}-2), 4.02(1 \mathrm{H}, \mathrm{m}, \mathrm{H}-1 \mathrm{a})$, $4.00\left(1 \mathrm{H}, \mathrm{m}, \mathrm{H}-2^{\prime}\right), 3.85\left(1 \mathrm{H}, \mathrm{dd}, 11.2 \mathrm{~Hz}, \mathrm{H}-6^{\prime \prime} \mathrm{a}\right), 3.79(1 \mathrm{H}, \mathrm{dd}, J=7.2 ; 14.8 \mathrm{~Hz}, \mathrm{H}-1 \mathrm{~b})$, $3.64\left(1 \mathrm{H}, \mathrm{dd}, J=4.4 ; 11.2 \mathrm{~Hz}, \mathrm{H}-6^{\prime \prime} \mathrm{b}\right), 3.57(1 \mathrm{H}, \mathrm{t}, J=6.1 \mathrm{~Hz}, \mathrm{H}-3), 3.50(1 \mathrm{H}, \mathrm{m}, \mathrm{H}-4), 3.33$ $\left(1 \mathrm{H}, \mathrm{m}, \mathrm{H}-3^{\prime \prime}\right), 3.27\left(1 \mathrm{H}, \mathrm{m}, \mathrm{H}-5^{\prime \prime}\right), 3.26\left(1 \mathrm{H}, \mathrm{dd}, J=12.3 ; 4 \mathrm{~Hz}, \mathrm{H}-4^{\prime \prime}\right), 2.01(1 \mathrm{H}, \mathrm{m}, \mathrm{H}-5 \mathrm{~b})$, $1.98(1 \mathrm{H}, \mathrm{m}, \mathrm{H}-5 \mathrm{a}), 1.73\left(1 \mathrm{H}, \mathrm{m}, \mathrm{H}-3^{\prime} \mathrm{a}\right), 1.64(1 \mathrm{H}, \mathrm{m}, \mathrm{H}-8), 1.63\left(1 \mathrm{H}, \mathrm{m}, \mathrm{H}-3^{\prime} \mathrm{b}\right), 1.28-1.40$ $\left(58 \mathrm{H}\right.$, brs, $\left.\mathrm{H}-9-16 / \mathrm{H}-4^{\prime}-24^{\prime}\right), 0.89\left(6 \mathrm{H}, \mathrm{t}, J=6.7 \mathrm{~Hz}, \mathrm{H}-17 / 25^{\prime}\right)$.

${ }^{13} \mathrm{C}-\mathrm{NMR}\left(\mathrm{CD}_{3} \mathrm{OD}, 100 \mathrm{MHz}\right)$ : $176.2\left(\mathrm{C}-\mathrm{1}^{\prime}\right), 130.4(\mathrm{C}-7), 129.4(\mathrm{C}-6), 103.3\left(\mathrm{C}-1^{\prime \prime}\right), 76.6$ $\left(\mathrm{C}-5^{\prime \prime}\right), 76.6\left(\mathrm{C}-3^{\prime \prime}\right), 74.4(\mathrm{C}-3), 73.6\left(\mathrm{C}-2^{\prime \prime}\right), 71.5\left(\mathrm{C}-2^{\prime}\right), 71.4(\mathrm{C}-4), 70.2\left(\mathrm{C}-4^{\prime \prime}\right), 68.5(\mathrm{C}-1)$, $61.3\left(\mathrm{C}-5^{\prime \prime}\right), 50.3(\mathrm{C}-2), 34.4\left(\mathrm{C}-3^{\prime}\right), 32.4$ (C-5), 32.0 (C-8), 22.2-31.7 (C-9-16/C-4'-24'), 13.1 $\left(\mathrm{C}-17 / \mathrm{C}-25^{\prime}\right)$.

\subsubsection{Methanolysis}

Compound $1(1 \mathrm{mg})$ was refluxed $\left(70^{\circ} \mathrm{C}\right)$ for $18 \mathrm{~h}$ in $2.5 \mathrm{~mL}$ of $\mathrm{MeOH}$ containing $1.5 \mathrm{~mL}$ of $0.9 \mathrm{~N} \mathrm{HCl}$ under magnetic stirring. The mixture was neutralized with aqueous solution of $\mathrm{Na}_{2} \mathrm{CO}_{3}$ and extracted with $\mathrm{CHCl}_{3}$. Methananolysis of 1 afforded methyl-2hydroxypentacosanoate. This fatty acid methyl ester was characterized by ESI-MS $[\mathrm{M}+\mathrm{H}]^{+}$at $\mathrm{m} / \mathrm{z} 413$ (Figure S13). Methyl-2-hydroxypentacosanoate: ESI-MS m/z: 413 $[\mathrm{M}+\mathrm{H}]^{+}, 393\left[\mathrm{M}-\mathrm{H}_{2} \mathrm{O}-\mathrm{H}\right]{ }^{+}, 365\left[\mathrm{M}-\mathrm{C}_{25} \mathrm{H}_{50} \mathrm{O}-\mathrm{H}\right]^{+}, 310\left[\mathrm{C}_{22} \mathrm{H}_{45}+\mathrm{H}\right]{ }^{+}$.

\subsection{Biological assay}

\subsubsection{Cytotoxicity assay}

The cytotoxicity assay was performed using the MTT assay as earlier described by Rahman-Atta-Ur and Thonsen (2001). Briefly, when the cells attained $90 \%$ confluence in microtiter plate, DMEM medium was replaced by a fresh one. Then, $1 \mu \mathrm{l}$ of stock solution of each compound and extract made in dimethylsulfoxide (DMSO) was diluted with complete medium to the final test concentration $(200 \mu \mathrm{g} / \mathrm{ml})$ into the 96-well 96-well microtiter plate and incubated for $72 \mathrm{~h}$. Moreover, the medium was removed and $200 \mu \mathrm{l}$ of 3-(4,5-dimethylthiazol-2-yl)-2,5-diphenyl tetrazolium bromide solution $(5 \mathrm{mg} / \mathrm{ml}, \mathrm{PBS}, \mathrm{pH} 7.2)$ (MTT, Sigma-Aldrich) and incubated at $37^{\circ} \mathrm{C}$ for $4 \mathrm{~h}$. Subsequently, the above solution was gently removed and $100 \mu$ of DMSO added in 
each well to dissolve the blue formazan crystals during $5 \mathrm{~min}$ at $37^{\circ} \mathrm{C}$. Finally, the absorbance was immediately read at $570 \mathrm{~nm}$ using bioassay plate reader (Molecular devices, Sunnyvale, CA, USA). These following different types of samples were included: medium blanks (growth medium with no cells or drugs), drug blank (growth medium with drug but no cells), positive control (cells treated with standard drug, actinomycin-D), negative control (cells untreated plus medium) and the test medium plus cells plus test compound or extract. This experiment was performed in triplicate. The inhibition percentage of compounds were determined by comparing with the untreated positive growth control. All data were compiled from a minimum of three experiments. Data for statistical analysis were expressed as the mean \pm standard deviation, $\mathrm{n}$ (number of experiments). One-way ANOVA with Dunnett's test, as specified, was performed using GraphPad Prism version 7.00 for Windows, GraphPad Software, San Diego California, USA. The following formula was used to calculate the percentage growth inhibition:

$$
\% \text { Inhibition }=100-\left(\frac{(\text { Test well }-0.1)}{(\text { Control well }-0.1)}\right) \times 100
$$

\subsubsection{Cell culture}

Cancer cell line Caco-2 was obtained from American Type Culture Collection (ATCC) and growth in sterile Costar T75 falcon containing DMEM (Sigma-Aldrich), which was supplemented with fetal bovine serum $(10 \%, \mathrm{v} / \mathrm{v}), 100 \mathrm{mg} / \mathrm{ml}$ streptomycin, $100 \mathrm{U} / \mathrm{ml}$ penicillin $\mathrm{G}$. Incubation was done at $37^{\circ} \mathrm{C}$ in $5 \% \mathrm{CO}_{2}$ atmosphere with $95 \%$ humidity. After $75-80 \%$ confluence, the cells were removed from the flask by treating with trypsin-EDTA solution ( $0.05 \%$, Gibco). A viable cells suspension of $5 \times 10^{4}$ cells $/ \mathrm{ml}$ was done and seeded into a 96-well microtiter plate (SPL Life sciences Co., Ltd Korea) and incubated. Visualization of the cells at each step was done microscopically and recorded with digital camera (Austria-Micros, LIB-302).

\section{Conclusion}

The species Tabernaemontana contorta Stapf, is known to be an abundant source of alkaloids, especially indole alkaloids. The bioactivity study of the isolated compounds indicated that compound $\mathbf{1}$ exhibited anti-colon cancer activity. Complementary investigations on compound $\mathbf{1}$ will be done to show the mechanisms of its anti-cancer effect, safety margin, lethal dose, effective dose, as well as in vivo studies.

\section{Acknowledgements}

We are grateful to the Department of Chemistry, Faculty of Science and Medicine from the University of Fribourg, Switzerland.

\section{Disclosure statement}

No potential conflict of interest was reported by the authors. 


\section{Funding}

University of Fribourg - Scholarships for foreign researchers 229779. This research was funded by University of Fribourg - Scholarships for foreign researchers - grant No. 229779.

\section{References}

Ai-Qun J, Xu Y, Wei-Xin W, Yong-Hong J. 2010. Glycocerebroside bearing a novel long-chain base from Sagina japonica (caryophyllaceae). Fitoterapia. 81(6):540-545.

Bui A-M, Debray M-M, Boiteau P, Potier P. 1977. Etude chimiotaxonomique de quelques especes de Hazunta. Phytochemistry. 16(6):703-706.

Burkill HM. 1985. The useful plants of west tropical Africa, families S-Z. Richmond (UK): Royal Botanic Gardens; p. 1954-1972.

Carothers S, Nyamwihura R, Collins J, Zhang H, Park H, Setzer W, Ogungbe I. 2018. Bauerenol acetate, the pentacyclic triterpenoid from Tabernaemontana longipes, is an antitrypanosomal agent. Molecules. 23(2):355.

Garcellano RC, Cort JR, Moinuddin SG, Franzblau SG, Ma R, Aguinaldo AM. 2019. An iboga alkaloid chemotaxonomic marker from endemic Tabernaemontana ternifolia with antitubercular activity. Nat Prod Res. 1-5. doi:10.1080/14786419.2018.1550759.

Foudjo Melacheu GL, Njoya EM, Jouda J-B, Kweka BNW, Mbazoa CD, Wang F, Wandji J. 2019. Two new indole alkaloids from Tabernaemontana contorta Stapf. Phytochem Lett. 30:116-119.

Gao JM, Dong ZJ, Liu JK. 2001. A new ceramides from the basidiomycete Russula cyanoxantha. Lipids. 36(2):175-180.

Huang Q, Tezuka Y, Hatanaka Y, Kikuchi T, Nishi A, Tubaki K. 1995. Studies on Metabolites of Mycoparasitic Fungi. IV. Minor Peptaibols of Trichoderma kiningii. Chem Pharm Bull. 43(10): 1663-1667.

Huang XZ, Yin Y, Dai JH, Liang H, Dai Y, Bai L. 2010. Two new ceramides from the stems of Piper betle L. Chin Chem Lett. 21(4):433-436.

Karlsson KA. 1970. Sphingolipids long chain bases. Lipids. 5(11):878-891.

Leeuwenberg AJM. 1994. A revision of Tabernaemontana. The new world species and stemmadenia, Vol 2. Kew (UK): Royal Botanic Gardens; p. 213-450.

Liu H, Orjala J, Sticher O, Rali T. 1999. Acylated flavonol glycosides from leaves of Stenochlaena palustris. J Nat Prod. 62(1):70-75.

Monnerat CS, Souza J. J D, Mathias L, Braz-Filho R, Vieira IJC. 2005. A new indole alkaloid isolated from Tabernaemontana hystrix steud (Apocynaceae). J Braz Chem Soc. 16(6b): 1331-1335.

Ndongo JT, Ngo Mbing J, Feussi T, Monteillier A, Pegnyemb DE, Cuendet M, Laatsch H. 2017. Indoline alkaloids from Tabernaemontana contorta with cancer chemopreventive activity. Phytochemistry. 144:189-196.

Ndongo JT, Ngo Mbing J, Aymeric M, Feussi T, RüTten M, Mombers D, Cuendet M, Pegnyemb DE, Birger D, and, Laatsch H. 2018. Carbazole, aspidofractinine and aspidocarpamine. Type alkaloids from Pleiocarpa pycnantha. J Nat Prod. 81:193-1202.

Patel MB, Miet C, Poisson J. 1967. A Revision of Tabernaemontana: alkaloids from some African Tabernaemontana. Ann Pharm Fr. 25(5):379-384.

Pauleti NN, Mello J, Siebert DA, Micke GA, de Albuquerque CAC, Alberton MD, Barauna SC. 2018. Characterisation of phenolic compounds of the ethyl acetate fraction from Tabernaemontana catharinensis and its potential antidepressant-like effect. Nat Prod Res. 32(16):1987-1990.

Pereira PS, França S. D C, Oliveira P. V A D, Breves C. M D S, Pereira SIV, Sampaio SV, Nomizo A, Dias DA. 2008. Chemical constituents from Tabernaemontana catharinensis root bark: a brief NMR review of indole alkaloids and in vitro cytotoxicity. Quím Nova. 31(1):20-24. 
Rahman-Atta-Ur CM, Thonsen WJ. 2001. Bioassay techniques for drug development. Amsterdam, the Netherlands: Harwood Academic Publishers; p. 28-29.

Rahmana SMM, Mukta AZ, Hossain MA. 2009. Isolation and characterization of $\beta$-sitosterolD-glycoside from petroleum extract of the leaves of Ocimum sanctum L. As J Food Ag-Ind. 2: 39-43.

Zhan ZJ, Yue JM. 2003. New glyceroglycolipid and ceramide from Premna microphylla. Lipids. 38(12):1299-1303. 